\title{
Titania/Electro-Reduced Graphene Oxide Nanohybrid as an Efficient Electrochemical Sensor for the Determination of Allura Red
}

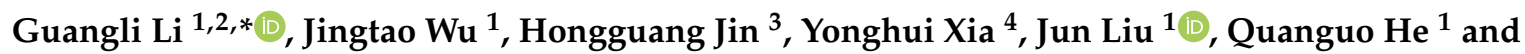 \\ Dongchu Chen ${ }^{2, *}$ \\ 1 College of Life Sciences and Chemistry, Hunan University of Technology, Zhuzhou 412007, China; \\ Jtwu123@163.com (J.W.); junliu@hut.edu.cn (J.L.); hequanguo@126.com (Q.H.) \\ 2 School of Materials Science and Energy Engineering, Foshan University, Foshan 528000, China \\ 3 College of Materials Science and Engineering, Changsha University of Science and Technology, \\ Changsha 410114, China; jesonjin08@csust.edu.cn \\ 4 Zhuzhou Institute for Food and Drug Control, Zhuzhou 412000, China; sunnyxia0710@163.com \\ * Correspondence: guangli010@hut.edu.cn (G.L.); chendc@fosu.edu.cn (D.C.); Tel.: +86-0731-2218-3382 (D.C.)
}

Received: 17 January 2020; Accepted: 5 February 2020; Published: 11 February 2020

\begin{abstract}
Titania/electro-reduced graphene oxide nanohybrids $\left(\mathrm{TiO}_{2} / \mathrm{ErGO}\right)$ were synthesized by the hydrolysis of titanium sulfate in graphene oxide suspension and in situ electrochemical reduction. It provides a facile and efficient method to obtain nanohybrids with $\mathrm{TiO}_{2}$ nanoparticles $\left(\mathrm{TiO}_{2}\right.$ NPs) uniformly coated by graphene nanoflakes. $\mathrm{TiO}_{2} /$ ErGO nanohybrids were characterized by transmission electron microscopy, X-ray diffraction, cyclic voltammogram, and electrochemical impedance spectroscopy in detail. Compared with pure ErGO and $\mathrm{TiO}_{2} \mathrm{NPs} \mathrm{TiO}_{2} / \mathrm{ErGO}_{\text {nanohybrids }}$ greatly enhanced the electrocatalytic activity and voltammetric response of Allura Red. In the concentration range of $0.5-5.0 \mu \mathrm{M}$, the anodic peak currents of Allura Red were linearly correlated to their concentrations. However, the linear relationship was changed to the semi-logarithmic relationship at a higher concentration region $(5.0-800 \mu \mathrm{M})$. The detection limit (LOD) was 0.05 $\mu \mathrm{M}$ at a signal-to-noise ratio of 3 . The superior sensing performances of the proposed sensor can be ascribed to the synergistic effect between $\mathrm{TiO}_{2} \mathrm{NPs}$ and ErGO, which provides a favorable microenvironment for the electrochemical oxidation of Allura Red. The proposed $\mathrm{TiO}_{2} / \mathrm{ErGO}_{\mathrm{GGCE}}$ showed good reproducibility and stability both in determination and in storage, and it can accurately detect the concentration of Allura Red in milk drinks, providing an efficient platform for the sensitive determination of Allura Red with high reliability, simplicity, and rapidness.
\end{abstract}

Keywords: $\mathrm{TiO}_{2}$; electro-reduced graphene oxide; Allura Red; voltammetric sensor

\section{Introduction}

Nowadays, the safety of food additives has become an increasingly important concern worldwide, since most of these substances are poisonous and even carcinogenic. Among diverse food additives, synthetic colorants have been extensively added into various soft beverages and foodstuffs to make them more attractive and appealing. However, some synthetic colorants can lead to adverse health issues, especially if they are excessively consumed [1,2]. Therefore, the use of synthetic colorants in foodstuffs were rigorously controlled by legislation all over the world. Allura Red (E 129) is a typical water-soluble azo dye, which was usually added to candies, syrups, and beverages to make a fascinating red color. Despite its widespread applications, the health threats cannot be underestimated, since its aromatic rings and azo groups may harm the human body. The European Food Safety Authority (EFSA, Parma, Italy) recommended that the acceptable daily intake (ADI) of Allura Red is $7.0 \mathrm{mg} / \mathrm{kg}$ 
bw/day [3]. In China, the maximum permitted dosage in soft beverages is $0.1 \mathrm{~g} / \mathrm{kg}$ referring to the national standard GB 2760-2014 [4]. Unfortunately, the dosages are frequently exceeded [5]. In Chinese regulation, the added colorants must be listed on commercial food labels, but their concentrations are not required. Therefore, it attaches great importance to detect Allura Red in foodstuffs to know their consumption, which is mainly due to the large and prolonged consumption of colorful foodstuffs and beverages.

Up to now, several analytical methods have been established for the routine detection of Allura Red, including spectrophotometry [2,6], high-performance liquid chromatography (HPLC) [7-9], cloud point extraction $[10,11]$, and capillary electrophoresis [12,13]. However, these analytical techniques are not always available and involve complicated and time-consuming pretreatment procedures that require expensive instruments and toxic solvents. In recent years, electroanalytical techniques have attracted growing attention and showed promising applications in sensing bioactive molecules and food contaminants due to their portability, cost-effective, rapid response, facile operation, and high sensitivity [14-21]. Therefore, it is feasible to miniaturize the devices for in situ determination. Allura Red contains an $-\mathrm{N}=\mathrm{N}-$ group, which is electrochemically active and can be reduced at the mercury electrodes [22,23]. Although these mercury electrodes have low detection limits, toxic mercury electrodes are not environmentally friendly and cause adverse health problems. Moreover, their reduction signals are susceptible to the soluble oxygen, which must be completely removed from the solution before electrochemical determination. Recently, some environmentally friendly mercury-free electrodes such as glassy carbon [24], antimony, and bismuth film electrodes [25-27] have been developed for the electrochemical detection of Allura Red. However, these mercury-free electrodes showed worse sensitivity, and cathodic peaks occurred at more negative potential compared to mercury electrodes. To address the above-mentioned issues, much effort has been made to develop novel modified electrodes that are capable of efficiently detecting Allura Red based on the oxidation signals. Novel electrochemical sensors based on multiwalled carbon nanotube (MWCNT) [28,29], ionic liquids [30], cobalt oxide [31], and cobalt complex [32] modified electrodes have shown great potentials on the detection of Allura Red, due to their excellent accumulation efficiency and large specific surface area. For example, MWCNT/GCE showed a wide linear response range of 496-4468 $\mu \mathrm{g} / \mathrm{L}$, and it was applied to the analysis of commercial isotonic sports drinks with satisfactory results [28]. The cobalt complex-decorated carbon paste electrode exhibited a wide linear response range of 60-1489 $\mu \mathrm{g} / \mathrm{L}$, and it was successfully applied in foods such as orange and strawberry-flavored gelatin, powders, soft drinks, and pharmaceutical dosages [32]. However, the anodic peaks generally appeared at a rather positive potential (above $0.7 \mathrm{~V}$ ), which may cause significant interfering from some species that are easily oxidized at such a high potential. In addition, some of the modification materials are not readily available and very expensive. Hence, finding more available, low-cost sensing materials that are capable of the electrocatalytic oxidation of Allura Red at lower potential remains challenging.

Titania nanoparticles $\left(\mathrm{TiO}_{2}\right.$ NPs) have become versatile materials for various (photo) electrochemical sensors and photocatalysts, owing to their fascinating properties including greater availability, low cost, good conductivity, strong adsorptive capacity, and efficient catalytic properties [33-42]. $\mathrm{TiO}_{2}$ NPs can be easily anchored on the surface of metal electrodes [43], but immobilizing them directly on the surface of glass carbon electrodes (GCE) is difficult. Due to their unique properties such as their large surface to-volume ratio, extraordinary electrical conductivity, and rapid electron transfer rate [44-48], graphene ( $\mathrm{Gr}$ ) has been considered as the most preferred electrode material for electrochemical sensors. Its unique 2D crystal structure and electronic property endows itself an ideal catalyst support for the anchoring of metal or metal oxide NPs [49], which offers versatile selective catalytic or sensing properties. Moreover, Gr can be easily decorated on the surface of GCE via $\pi-\pi$ interaction. Hence, graphene is a suitable support to disperse and stabilize $\mathrm{TiO}_{2}$ NPs. For these reasons, $\mathrm{TiO}_{2} / \mathrm{Gr}$ nanohybrids have exhibited greater versatility as advanced sensing materials for the sensitive detection of adenine [36], guanine [36], glucose [50], dopamine [51], 
paracetamol [52], L-tryptophan [53], L-tyrosine [53], etc. However, to our best knowledge, $\mathrm{TiO}_{2} / \mathrm{Gr}$ nanohybrids have been rarely used for the detection of Allura Red.

Herein, $\mathrm{TiO}_{2} / \mathrm{Gr}$ nanohybrids were synthesized for the sensitive detection of Allura Red in soft drinks. $\mathrm{TiO}_{2} /$ electro-reduced graphene oxide nanohybrids $\left(\mathrm{TiO}_{2} / \mathrm{ErGO}\right)$ were synthesized by the hydrolysis of titanium sulfate in graphene oxide (GO) suspension and in situ electrochemical reduction. In this way, the oxygen-containing functional groups present in graphene oxide can be reduced with the application of the appropriate potential. The electrical conductivity was greatly improved due to the restoration of carbon-conjugated networks after electrochemical reduction. Compared with chemical and thermal reduction methods, the electrochemical reduction is very simple and time-saving. Moreover, no any poisonous and potentially explosive chemicals such as hydrazine and sodium borohydride are not required. The synergistic effect between $\mathrm{TiO}_{2} \mathrm{NPs}$ and ErGO nanosheets greatly improved the electrochemical oxidation of Allura Red, with remarkably enhanced voltammetric response and decreased anodic peak potential. Moreover, the proposed $\mathrm{TiO}_{2} /$ ErGO exhibited good selectivity, sensitivity, and stability for the detection of Allura Red.

\section{Materials and Methods}

\subsection{Chemicals}

Allura Red, amaranth, $\mathrm{K}_{3}\left[\mathrm{Fe}(\mathrm{CN})_{6}\right], \mathrm{K}_{4}\left[\mathrm{Fe}(\mathrm{CN})_{6}\right], \mathrm{KCl}, \mathrm{Na}_{2} \mathrm{HPO}_{4}$, and $\mathrm{NaH}_{2} \mathrm{PO}_{4}$ were supplied by Aladdin Reagents Co., Ltd (www.aladdin-e.com, Shanghai, China). All the reagents were of analytical grade and directly used as received. GO was purchased from Xianfeng NANO Material Tech Inc. (Nanjing, China). Liziyuan milk drinking was purchased from a local supermarket.

\subsection{Prepration of $\mathrm{TiO}_{2} / \mathrm{GO}$ Nanocomposites}

$\mathrm{TiO}_{2} \mathrm{NPs}$ were synthesized by the hydrolysis of titanium sulfate in GO suspension. Typically, $40 \mathrm{mg}$ of GO was dispersed in a mixed solvent of ethanol $(10 \mathrm{~mL})$ and water $(20 \mathrm{~mL})$ under $0.5 \mathrm{~h}$ of ultrasonication to obtain a homogenous suspension of exfoliated GO. Then, $6.2 \mathrm{mg}$ of titanium sulfate was added to the GO suspension and ultrasonicated for $0.5 \mathrm{~h}$. Afterwards, the resultant solution was transferred to a $50-\mathrm{mL}$ autoclave and reacted at $180{ }^{\circ} \mathrm{C}$ for $4 \mathrm{~h}$. After it was cooled to room temperature, the reaction solution was centrifuged at a rate of $11,000 \mathrm{r} / \mathrm{min}$ for $10 \mathrm{~min}$. Subsequently, the solids were repeatedly washed with absolute ethanol and deionized water for 2-3 rounds; then, they were vacuum-dried at $60^{\circ} \mathrm{C}$ overnight. The $\mathrm{TiO}_{2} / \mathrm{GO}$ nanohybrids were obtained as black powder. The as-obtained $\mathrm{TiO}_{2} / \mathrm{GO}$ nanohybrids $(10 \mathrm{mg}$ ) were ultrasonically dispersed in $10 \mathrm{~mL}$ of deionized water for $2 \mathrm{~h}$ to get a homogenous dispersion $(1 \mathrm{mg} / \mathrm{mL})$.

\subsection{Preparation of $\mathrm{TiO}_{2} /$ ErGO Modified Electrodes}

Prior to electrode modification, bare GCEs were carefully polished to mirror-like surface at a cloth pad using $0.05 \mu \mathrm{m} \mathrm{Al} \mathrm{O}_{3}$ slurry; then, they were alternately cleaned by anhydrous alcohol and deionized water. The freshly polished GCEs were dried under an infrared lamp. $\mathrm{TiO}_{2} / \mathrm{ErGO} / \mathrm{GCE}$ were prepared by a simple drop-casting and in situ electrochemical reduction technique. Typically, $5 \mu \mathrm{L}$ of $\mathrm{TiO}_{2} / \mathrm{GO}$ dispersion was dropped and casted on the surface of GCEs; then, it was allowed to dry under an infrared lamp. Finally, the $\mathrm{TiO}_{2} / \mathrm{GO} / \mathrm{GCE}$ s were immersed into $0.1 \mathrm{M}$ PBS solution $(\mathrm{pH}=6.0)$ and electrochemically reduced at $-1.2 \mathrm{~V}$ for $2 \mathrm{~min}$. For comparison, individual $\mathrm{TiO}_{2} \mathrm{NPs}$ and ErGO-modified GCEs were also manufactured by the same procedure.

\subsection{Electrochemical Detection of Allura Red}

A classical three-electrode assembly was used in all the electrochemical measurements, consisting of a bare or modified GCE, a saturated calomel electrode (SCE), and a platinum wire as the working electrode, reference electrode, and auxiliary electrode, respectively. First, $0.1 \mathrm{M}$ of phosphate buffer solution (PBS, pH 7.0) was used as the supporting electrolyte unless otherwise stated. To assess 
the electrochemical properties of the proposed sensor, cyclic voltammogram and electrochemical impedance spectroscopy was recorded in $0.1 \mathrm{mM}\left[\mathrm{Fe}(\mathrm{CN})_{6}\right]^{3-/ 4-}$ probe solution. Electrochemical impedance spectroscopy was scanned from 100,000 to $0.1 \mathrm{~Hz}$ at open circuit potential using a $5 \mathrm{mV}$ (rms) AC sinusoid signal. After a suitable accumulation, the differential pulse voltammetry (DPV) was measured from 0.3 to $0.9 \mathrm{~V}$. The pulse amplitude is $0.05 \mathrm{~V}$, the pulse width is $0.05 \mathrm{~s}$, the sample width is $0.0167 \mathrm{~s}$, and the pulse period is $0.2 \mathrm{~s}$.

\section{Results and Discussions}

\subsection{Materials Chararazation}

The microstructures of $\mathrm{TiO}_{2} \mathrm{NPs}$ and $\mathrm{TiO}_{2} / \mathrm{ErGO}$ nanohybrids were investigated by transmission electron microscopy (TEM). Cube-like structures were observed in Figure 1A, and the particle sizes of $\mathrm{TiO}_{2} \mathrm{NPs}$ are estimated to $30-50 \mathrm{~nm}$. After introducing ErGO sheets onto the surface of $\mathrm{TiO}_{2} \mathrm{NPs}$, $\mathrm{TiO}_{2} \mathrm{NPs}$ were wrapped and coated by ErGO nanoflakes (Figure 1B), confirming that $\mathrm{TiO}_{2} \mathrm{NPs}$ were successfully hybridized with ErGO nanoflakes.

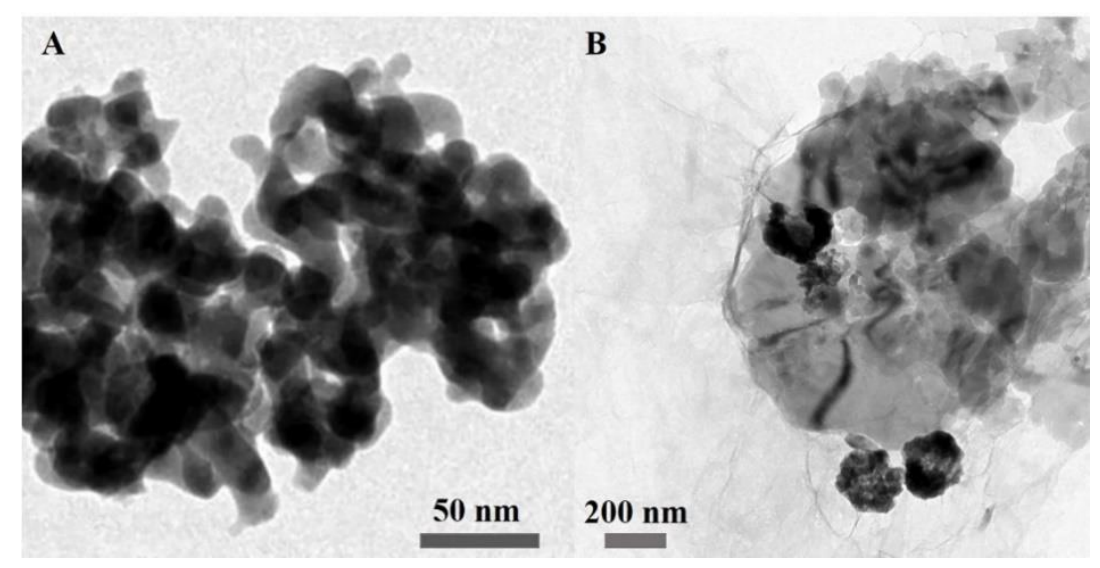

Figure 1. TEM images of $\mathrm{TiO}_{2}$ nanoparticles $\left(\mathrm{TiO}_{2} \mathrm{NPs}\right)(\mathbf{A})$ and electro-reduced graphene oxide nanohybrids $\left(\mathrm{TiO}_{2} /\right.$ ErGO) nanohybrids $(\mathbf{B})$.

The crystalline structures of $\mathrm{TiO}_{2} \mathrm{NPs}$, GO nanoflakes, and $\mathrm{TiO}_{2} / \mathrm{GO}$ nanohybrids were further investigated by X-ray diffraction (XRD). As shown in Figure 2A, pronounced diffraction peaks appear at $25.26^{\circ}, 36.92^{\circ}, 47.94^{\circ}, 53.98^{\circ}, 54.90^{\circ}, 62.60^{\circ}, 68.86^{\circ}, 70.08^{\circ}$, and $75.06^{\circ}$, respectively, which can be well assigned to (101), (004), (200), (105), (211), (213), (116), (220), and (215) crystal planes of anatase $\mathrm{TiO}_{2}$ (JCPDS card 21-1272), respectively. Moreover, no visible impurity peaks were observed. The results suggest that the as-obtained $\mathrm{TiO}_{2} \mathrm{NPs}$ have anatase structure with good crystallinity. The XRD pattern of GO shows a sharp diffraction peak at $2 \Theta=10.6^{\circ}$ (Figure 2B), which can be indexed to the (001) crystal plane of $\mathrm{GO}$ with a d-spacing of $0.80 \mathrm{~nm}$ [54]. In the XRD pattern of the $\mathrm{TiO}_{2} / \mathrm{GO}$ nanocomposite in Figure 2C, the major characteristic peaks of $\mathrm{GO}$ can also be identified in addition to $\mathrm{TiO}_{2}$ peaks. The results indicate that the $\mathrm{TiO}_{2} / \mathrm{GO}$ nanocomposite was successfully prepared. 


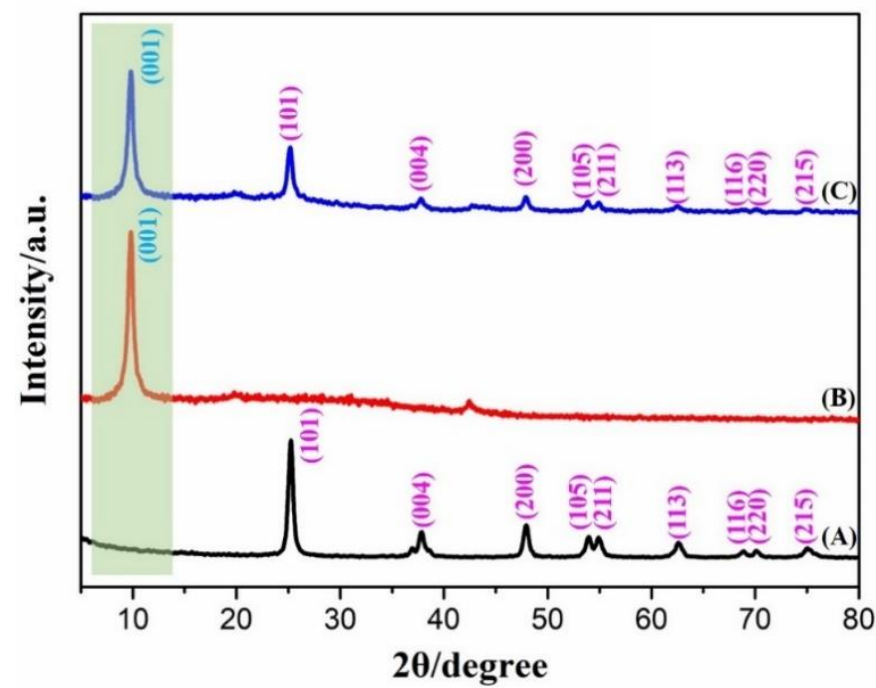

Figure 2. XRD patterns of $\mathrm{TiO}_{2} \mathrm{NPs}(\mathbf{A})$, graphene oxide (GO) nanosheets (B), and $\mathrm{TiO}_{2} / \mathrm{GO}$ nanohybrids $(\mathbf{C})$.

The Fourier transform infrared spectroscopy (FTIR) of GO and ErGO are shown in Figure 3. In the FTIR of GO, apparent peaks at 1725, 1618, 1407, 1225, and $1057 \mathrm{~cm}^{-1}$ are assigned to the characteristic peaks of $\mathrm{C}=\mathrm{O}$ (carbonyl or carboxy), $\mathrm{C}=\mathrm{C}$ (aromatics), $\mathrm{C}-\mathrm{O}$ (carboxy), C-O (epoxy), and C-O (alkoxy), respectively. As expected, these oxygen-containing functional groups almost disappear, indicating that graphene oxide was successfully electrochemically reduced into reduced graphene oxide.

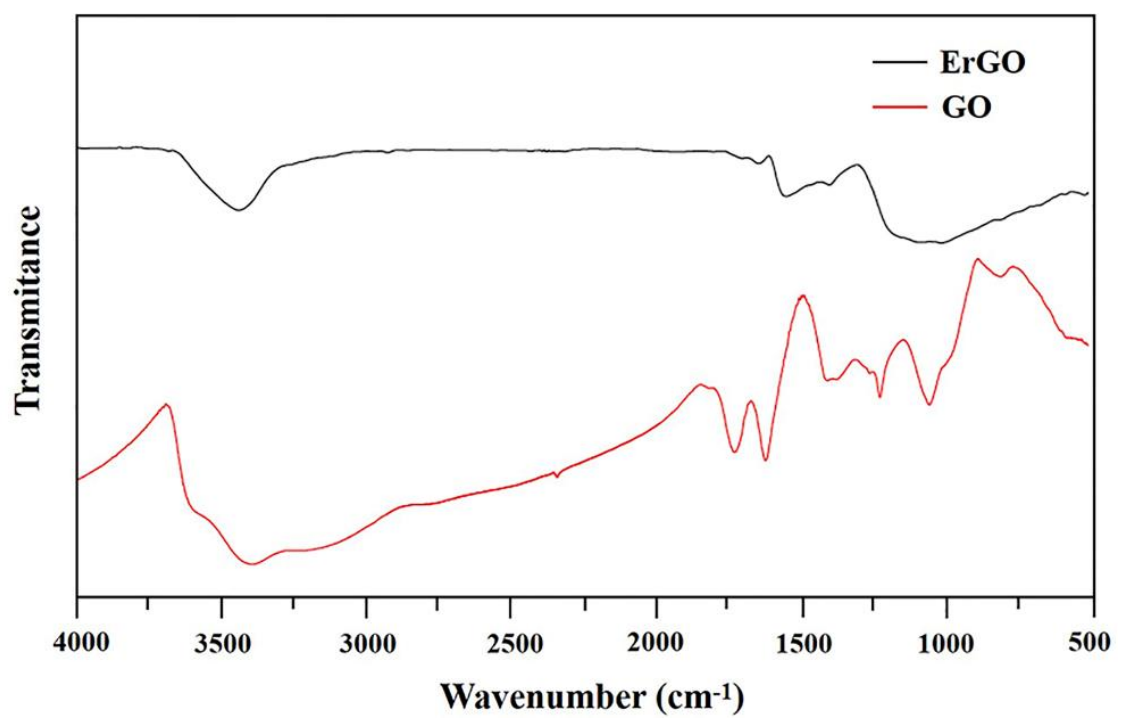

Figure 3. FTIR spectra of graphene oxide (GO) and electro-reduced graphene oxide (ErGO).

\subsection{Assessement of Electrochemical Properties}

To assess the electrochemical properties, cyclic voltammograms for different modified electrodes were recorded in $0.1 \mathrm{M}\left[\mathrm{Fe}(\mathrm{CN})_{6}\right]^{3-/ 4-}$ and $\mathrm{KCl}$ mixture solution. As shown in Figure $4 \mathrm{~A}$, the ratios of anodic and cathodic peak currents $\left(i_{\mathrm{pa}} / \mathrm{i}_{\mathrm{pc}}\right)$ approach to 1 for all electrodes, suggesting that all electrodes experience a quasi-reversible process. The redox peak currents increase in the following order: bare GCE, $\mathrm{TiO}_{2} / \mathrm{GCE}$, ErGO/GCE, and $\mathrm{TiO}_{2} / \mathrm{ErGO} / \mathrm{GCE}$. Among these electrodes, $\mathrm{TiO}_{2} / \mathrm{ErGO}_{\mathrm{GGE}}$ shows the largest electrochemical response, with $i_{p a}$ and $i_{p c}$ of 148.2 and $144.1 \mu \mathrm{A}$, respectively. Moreover, the peak separation between anodic and cathodic peaks $\left(\Delta \mathrm{E}_{\mathrm{p}}=67 \mathrm{mV}\right)$ is the smallest. All these results demonstrate the synergistic effect between $\mathrm{TiO}_{2}$ NPs and ErGO. Referring to the 
Randles-Sevcik equation [18,46], the effective electroactive areas of bare GCE, $\mathrm{TiO}_{2} / \mathrm{GCE}$, ErGO/GCE, and $\mathrm{TiO}_{2} / \mathrm{ErGO} / \mathrm{GCE}$ were estimated to $0.0768,0.0959,0.1052$, and $0.1308 \mathrm{~cm}^{2}$, respectively. The effective electroactive area of $\mathrm{TiO}_{2} / \mathrm{ErGO} / \mathrm{GCE}$ is twice of that of bare GCE approximately. The results indicate that $\mathrm{TiO}_{2} / \mathrm{ErGO}$ nanohybrids greatly increase the electroactive surface area, which will eventually boost the electrochemical responses.
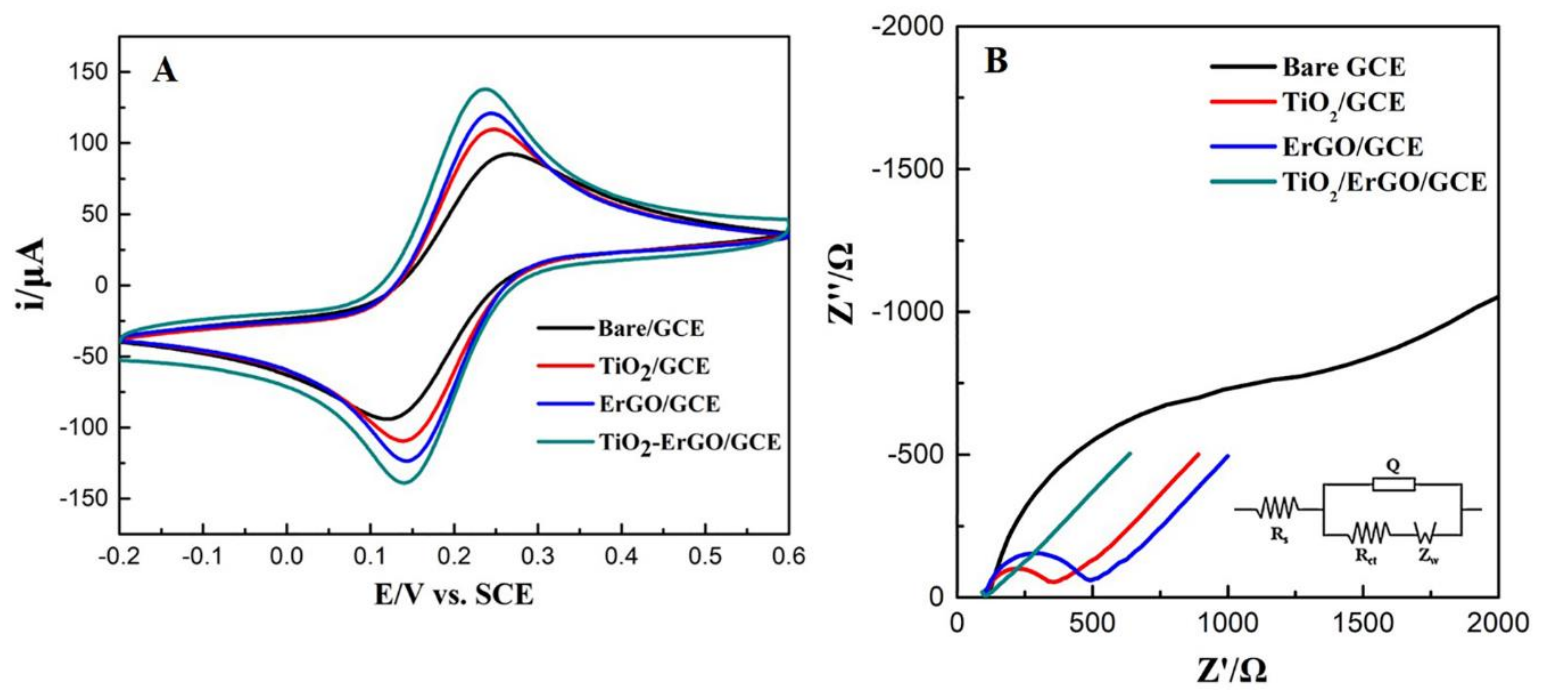

Figure 4. Cyclic voltammograms (A) and Nyquist plots (B) measured at different electrodes in $0.1 \mathrm{mM}$ $\left[\mathrm{Fe}(\mathrm{CN})_{6}\right]^{3-/ 4-}$ and $\mathrm{KCl}$ mixture solution. The inset in Figure $4 \mathrm{~B}$ represents the equivalent circuit model.

Electrochemical impedance spectroscopy is a valuable tool to investigate the charge transfer ability between electrode and electrolyte interfaces $[18,46,55,56]$. Nyquist plots includes the semicircular at high frequencies and linear portions at low frequencies, which are closely associated with the electron transfer-limited process and diffusion-controlled process, respectively. Generally, the charge transfer resistance $\left(R_{c t}\right)$ equals a semicircle diameter. As shown in Figure $4 B$, the $R_{c t}$ value decreases from $1562 \Omega$ to $341 \Omega$ and $211 \Omega$ after loading ErGO nanosheets and $\mathrm{TiO}_{2}$ NPs onto the bare electrode, respectively, which means that the charge transfer between the electrode and solution is more efficient after the modification with electrode by ErGO and $\mathrm{TiO}_{2} \mathrm{NPs}$. In other words, both $\mathrm{TiO}_{2} \mathrm{NPs}$ and ErGO nanosheets can significantly improve the electron transfer efficiency. As expected, a notable decrease in the semicircle diameter $\left(\mathrm{R}_{\mathrm{ct}}=14.5 \Omega\right)$ is found on the $\mathrm{TiO}_{2} / \mathrm{ErGO} / \mathrm{GCE}$. It is believed that the remarkably decreased $R_{\mathrm{ct}}$ can promote the electrochemical sensing performance.

\subsection{Electrochemical Response of Allura Red on Different Modified Electrodes}

DPV responses of $100 \mu \mathrm{M}$ Allura Red were recorded at different electrodes (Figure 5). Clearly, the anodic peak current of Allura Red at bare GCE is weakest $\left(\mathrm{i}_{\mathrm{pa}}=0.607 \mu \mathrm{A}\right)$. After introducing $\mathrm{TiO}_{2} \mathrm{NPs}_{\text {, }}$ the anodic peak current of Allura Red increased to $0.768 \mu \mathrm{A}$ due to the good electrocatalytic activity and high adsorptive ability [36,50-52]. When the GCE was decorated with $\mathrm{TiO}_{2} / \mathrm{ErGO}$ nanohybrids, the anodic peak current of Allura Red greatly increases $\left(i_{p a}=0.890 \mu \mathrm{A}\right)$, owing to the combined effect from good electrical conductivity and high specific surface area, which facilitates the absorption efficiency and electrochemical reactivity of Allura Red [52]. As expected, $\mathrm{TiO}_{2} / \mathrm{ErGO} / \mathrm{GCE}$ shows the largest response signal $\left(\mathrm{i}_{\mathrm{pa}}=1.187 \mu \mathrm{A}\right)$. The anodic peak potentials $\left(\mathrm{E}_{\mathrm{pa}}\right)$ of bare $\mathrm{GCE}, \mathrm{TiO}_{2} / \mathrm{GCE}$, $\mathrm{ErGO} / \mathrm{GCE}$, and $\mathrm{TiO}_{2} / \mathrm{ErGO} / \mathrm{GCE}$ are $0.648,0.642,0.624$, and $0.620 \mathrm{~V}$, respectively. Interestingly, the anodic peak potential at $\mathrm{TiO}_{2} / \mathrm{ErGO} / \mathrm{GCE}$ is lower compared with previous reports [28,29,32,57], which can effectively avoid the co-oxidation of other interferences that may coexist in food with Allura Red. It probably because $\mathrm{TiO}_{2} / \mathrm{ErGO}$ nanohybrids can effectively accelerate the electron transfer between and analyte, thus minimizing the activated polarization potential. The enhancement on the peak current and lowering of oxidation overpotential demonstrate that $\mathrm{TiO}_{2} / \mathrm{ErGO}$ nanohybrids have 
superior electrocatalytic activity toward the oxidation of Allura Red. It can be reasonably ascribed to the synergistic effect between $\mathrm{TiO}_{2} \mathrm{NPs}$ and ErGO nanosheets, which combines the unique properties of two individual components. The electrocatalytic effect and cumulate accumulation capability of $\mathrm{TiO}_{2} / \mathrm{ErGO}$ nanohybrids accelerate electron transfer and eventually improve the electrochemical sensing performances [36,50-53].

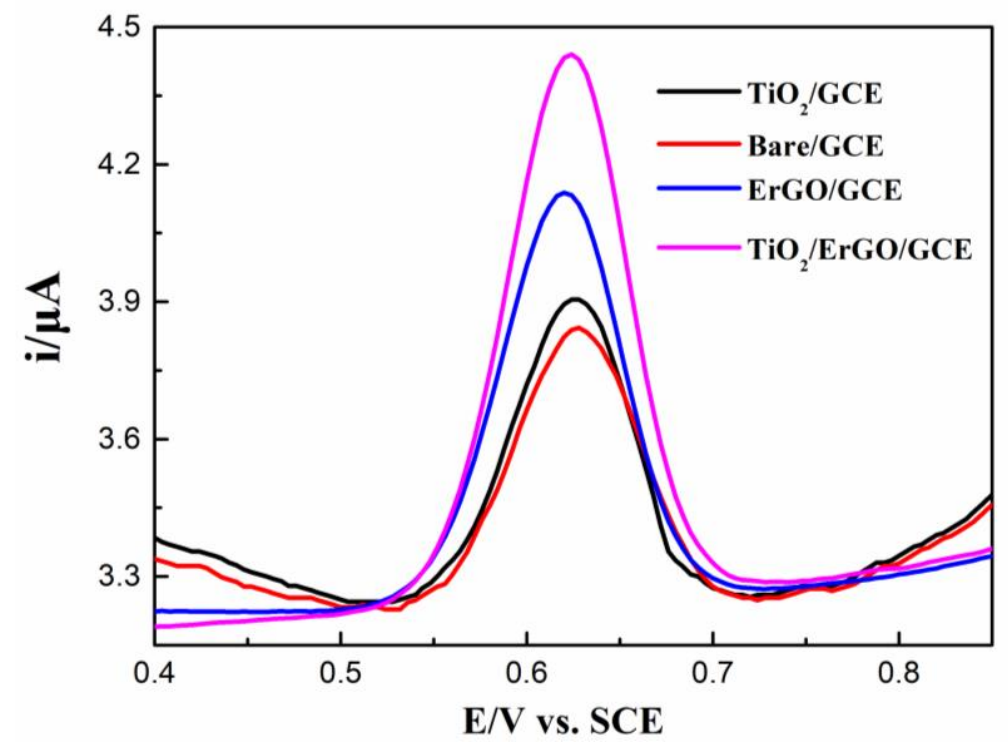

Figure 5. Differential pulse voltammetry (DPVs) of $100 \mu \mathrm{M}$ Allura Red recorded at different modified electrodes.

\subsection{Optimization of Analytical Conditions}

\subsubsection{Effect of $\mathrm{pH}$}

The effect of $\mathrm{pH}$ on the response anodic peak current of Allura Red was explored by DPV. As displayed in Figure 6A, the anodic peaks of Allura Red shifts toward a negative potential direction, which demonstrate the proton participant in the redox process of Allura Red. The anodic peak currents of Allura Red gradually increase with $\mathrm{pH}$ varying from 5.6 to 7.0 ; then, they slowly decrease when the $\mathrm{pH}$ exceeds 7.0 (Figure 6B). Therefore, $\mathrm{pH} 7.0$ was selected as the optimal $\mathrm{pH}$. In addition, the anodic peak potentials of Allura is inversely related to $\mathrm{pH}$, with the linear expression of $E_{\mathrm{pa}}=-0.048 \mathrm{pH}+$ $0.881\left(\mathrm{R}^{2}=0.987\right)$. The slope $(48 \mathrm{mV} / \mathrm{pH})$ is close to the theoretical value $(59 \mathrm{mV} / \mathrm{pH})$, indicating an electrochemical process involving an equal number of electrons $\left(\mathrm{e}^{-}\right)$and protons $\left(\mathrm{H}^{+}\right)$.
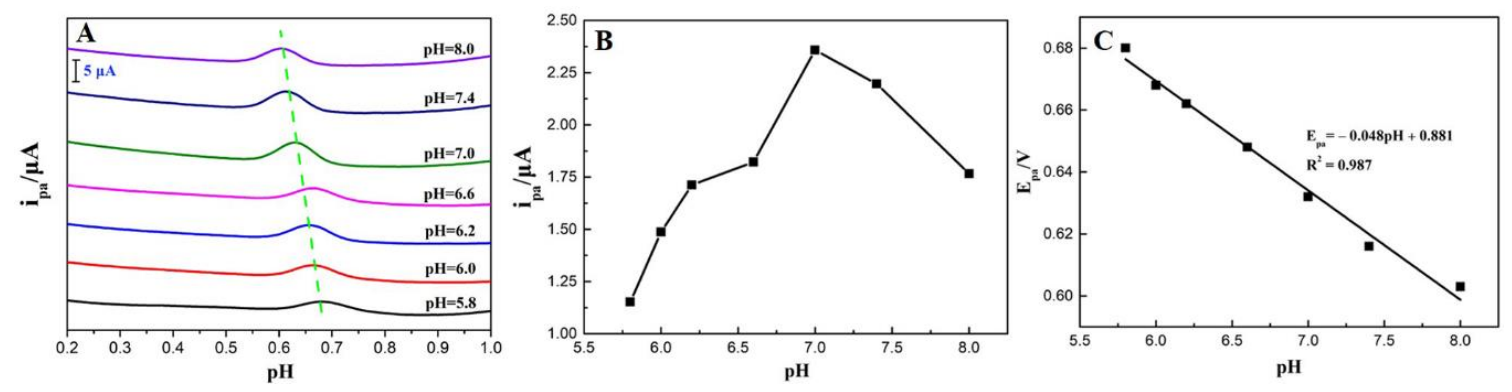

Figure 6. (A) DPV curves of Allura Red recorded at various $\mathrm{pH}$; (B) The influence of $\mathrm{pH}$ on the anodic peak current of Allura Red; $(\mathbf{C})$ Linear relationship between anodic peak potential and $\mathrm{pH}$. 


\subsubsection{Effect of Scan Rates}

To understand the electrochemical mechanism for the redox of Allura Red, cyclic voltammograms of $10 \mu \mathrm{M}$ Allura Red were measured by $\mathrm{TiO}_{2} / \mathrm{ErGO} / \mathrm{GCE}$ at various scan rates. Cyclic voltammograms at different scan rates are shown in Figure 7A. A pair of redox peaks are observed at all scan rates with the ratio of $\mathrm{i}_{\text {pa }} / \mathrm{i}_{\mathrm{pc}}$ approaching 1 , demonstrating that a quasi-reversible process occurs at $\mathrm{TiO}_{2} / \mathrm{ErGO}_{\mathrm{GCE}}$. The anodic peak currents gradually increase with the increasing of scan rates. In addition, as the scan rates speed up, the anodic peaks of Allura Red shift positively, while the cathodic peaks move to the reverse direction. As shown in Figure $7 \mathrm{~B}$, there are good linear relationships between anodic/cathodic peak currents $\left(i_{\mathrm{pa}}\right.$ or $\left.i_{\mathrm{pc}}\right)$ and the square root of scan rates $\left(v^{1 / 2}\right)$. Their linear equations are $i_{\text {pa }}$ $(\mu \mathrm{A})=5.875 v^{1 / 2}(\mathrm{~V} / \mathrm{s})-0.460\left(\mathrm{R}^{2}=0.999\right)$ and $\mathrm{i}_{\mathrm{pa}}(\mu \mathrm{A})=5.875 v^{1 / 2}(\mathrm{~V} / \mathrm{s})-0.460\left(\mathrm{R}^{2}=0.993\right)$, respectively. This result indicates that the redox of Allura Red is a typical diffusion-limited process. Moreover, the anodic or cathodic peak potentials are highly correlated to the Napierian logarithm of scan rates (Figure 7C). Their linear regression equations can be expressed as $\mathrm{E}_{\mathrm{pa}}(\mathrm{V})=0.036 \ln v(\mathrm{~V} / \mathrm{s})+0.777$ and $\mathrm{E}_{\mathrm{pc}}(\mathrm{V})=-0.023 \ln v(\mathrm{~V} / \mathrm{s})+0.570$, with a correlation coefficient $\left(\mathrm{R}^{2}\right)$ of 0.982 and 0.973 , respectively. As for a diffusion-limited quasi-reversible process, the relationship between redox potential ( $\mathrm{E}_{\mathrm{pa}}$ or $\left.\mathrm{E}_{\mathrm{pc}}\right)$ and $\ln v$ should follow Laviron's equations [58,59].

$$
\begin{gathered}
\mathrm{E}_{\mathrm{pa}}=\mathrm{E}_{0}^{\prime}+\frac{R T}{(1-\alpha) n F}\left[0.78+\ln \left(D^{1 / 2} k_{s}^{-1}\right)-\frac{R T}{2(1-\alpha) n F}\right]+\frac{R T}{2(1-\alpha) n F} \ln v \\
\mathrm{E}_{\mathrm{pc}}=\mathrm{E}_{0}^{\prime}-\frac{R T}{\alpha n F}\left[0.78+\ln \left(D^{1 / 2} k_{s}^{-1}\right)-\frac{R T}{2 \alpha n F}\right] \ln v-\frac{R T}{2 \alpha n F} \ln v \\
\ln k_{s}=\alpha \ln (1-\alpha)+(1-\alpha) \ln \alpha-\ln \frac{R T}{n F v}-\frac{(1-\alpha) n \alpha \Delta \mathrm{E}_{p}}{R T}
\end{gathered}
$$

where $\alpha$ is the charge transfer coefficient, $n$ is the electron transferred number, and other symbols have the usual meanings. Combining the linear relationships with Lavrion's equations, the charge transfer coefficient $(\alpha)$ is calculated as 0.6 . Then, the electron transfer number $(n)$ is found to $0.89 \approx 1.0$, indicating a one-electron transferred electrochemical process of Allura Red at $\mathrm{TiO}_{2} / \mathrm{ErGO} / \mathrm{GCE}$. Based on the earlier discussion that the electrochemical oxidation of Allura Red at $\mathrm{TiO}_{2} / \mathrm{ErGO} / \mathrm{GCE}$ was a process related to an equal numbers of electrons and protons, it's deduced that the reaction mechanism of Allura Red involves one electron and one proton transfer, which is caused by the phenolic hydroxy (Scheme 1). The reaction mechanism is in good agreement with the previous report [4].
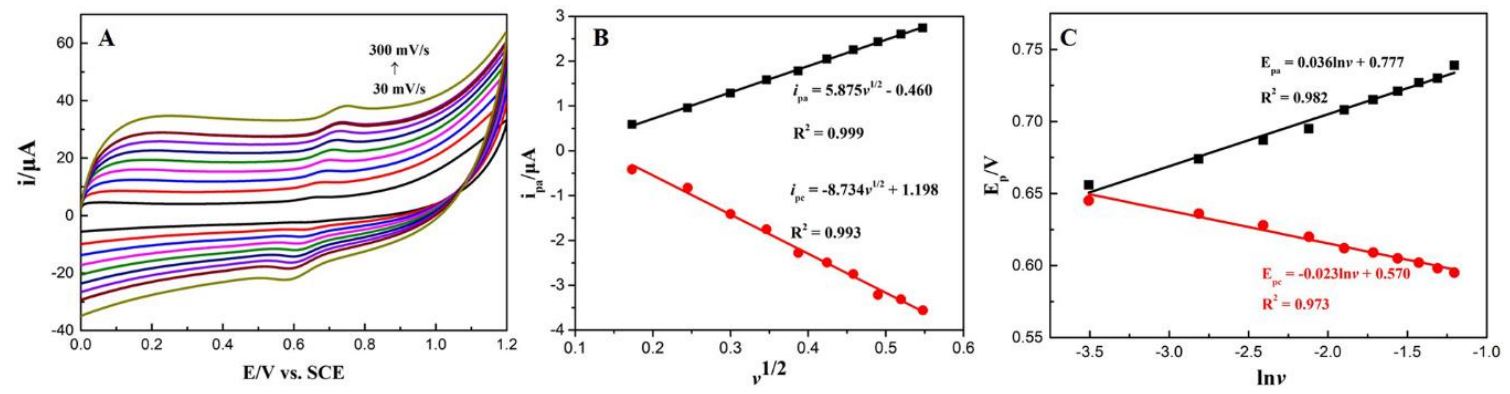

Figure 7. (A) Cyclic voltammograms of $10 \mu \mathrm{M}$ of Allura Red at various scan rates. (B) Linear plots of anodic and cathodic peak currents of Allura Red against the square root of scan rates $\left(v^{1 / 2}\right)$; (C) Linear plots of anodic and cathodic peak potentials against the Napierian logarithm of scan rates $(\ln v)$. 

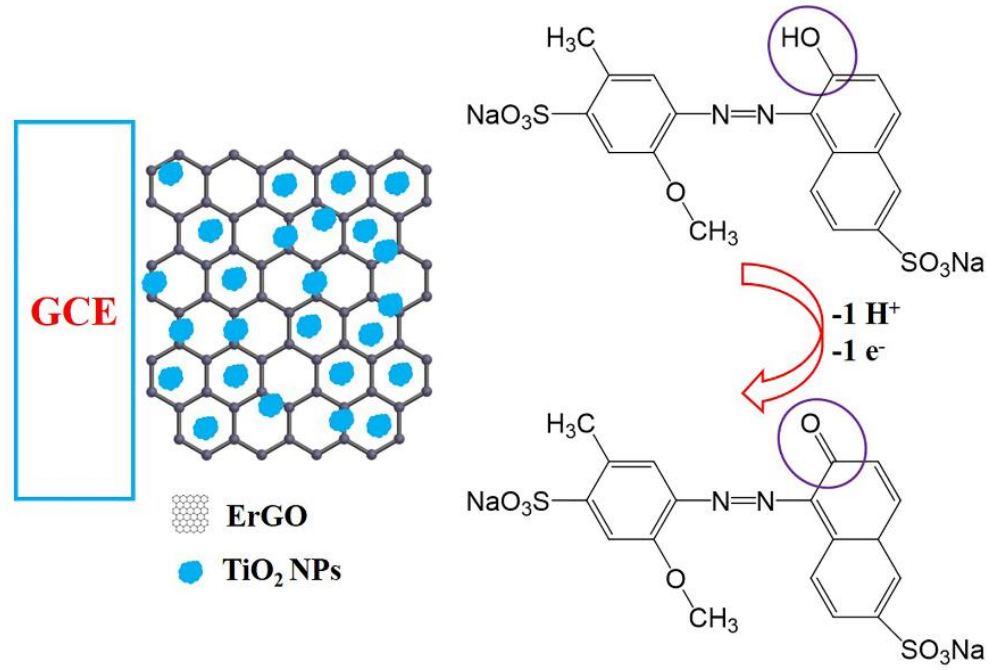

Scheme 1. Schematic diagram of the electrochemical mechanism for the redox of Allura Red at $\mathrm{TiO}_{2} / \mathrm{ErGO} / \mathrm{GCE}$.

\subsubsection{Effect of Accumulation Parameters}

The effect of accumulation time as well as potential were also investigated (Figure 7). As shown in Figure 8A, the anodic peak currents of Allura Red gradually increase for $150 \mathrm{~s}$; then, they suddenly decrease with the further extension of accumulation time. So, $150 \mathrm{~s}$ was recommended as the optimal accumulation time. When the accumulation potentials were changed from $-0.5 \mathrm{~V}$ to $-0.3 \mathrm{~V}$, their anodic peak currents gradually increase. However, they slowly decrease when the accumulation potential went beyond $-0.3 \mathrm{~V}$ (Figure $8 \mathrm{~B}$ ). Hence, $-0.3 \mathrm{~V}$ was chosen as the optimal accumulation potential. The optimal accumulation parameters $(-0.3 \mathrm{~V}, 150 \mathrm{~s})$ were adopted in the following measurements.
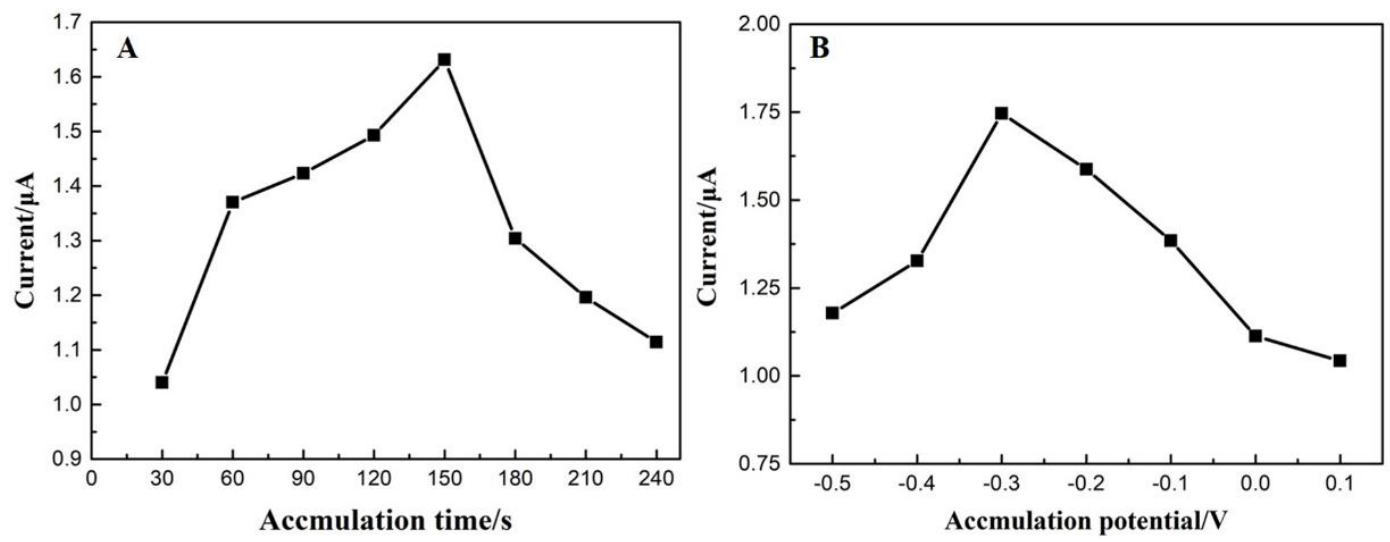

Figure 8. Influence of accumulation time (A) and accumulation potential (B) on the anodic peak currents of Allura Red.

\subsection{Selectivity, Reproducibility, and Stability}

To assess the selectivity of the proposed sensor, the DPV responses of Allura Red in the presence of common inorganic metal ions (e.g., $\mathrm{K}^{+}, \mathrm{Na}^{+}, \mathrm{Ca}^{2+}, \mathrm{Mg}^{2+}$ ) and amaranth were also measured. The relative errors lower than $5 \%$ in the coexistence of 100 -fold of these potential interfering substances (Figure 9A), indicating excellent anti-jamming performance. It is worth pointing out that the anodic peaks of Allura Red and amaranth are well separated with rather wide peak-to-peak separation $\left(\Delta \mathrm{E}_{\mathrm{p}}\right)$ of $0.252 \mathrm{~V}$. Moreover, the andic peak current of Allura Red is hardly changed even in the existence of 100-fold amaranth. The phenomenon also shows that it is feasible to detect Allura Red and amaranth simultaneously. To check repeatability, seven successive measurements were also carried out. 
The relative standard deviation (RSD) is $5.46 \%$, suggesting that $\mathrm{TiO}_{2} / \mathrm{ErGO} / \mathrm{GCE}$ have good repeatability (Figure 9B). Then, anodic peak currents of Allura Red were recorded at seven $\mathrm{TiO}_{2} / \mathrm{ErGO} \mathrm{GCEs}$ that were fabricated by the same procedure, aiming to evaluate electrode reproducibility (Figure 9C). The RSD of $4.83 \%$ is acceptable, demonstrating electrode fabrication that has good reproducibility. Finally, the anodic peak currents of Allura Red were monitored during two weeks. After two weeks, the anodic peak current of Allura Red retains $90.9 \%$ of its original value, demonstrating good stability (Figure 9D).
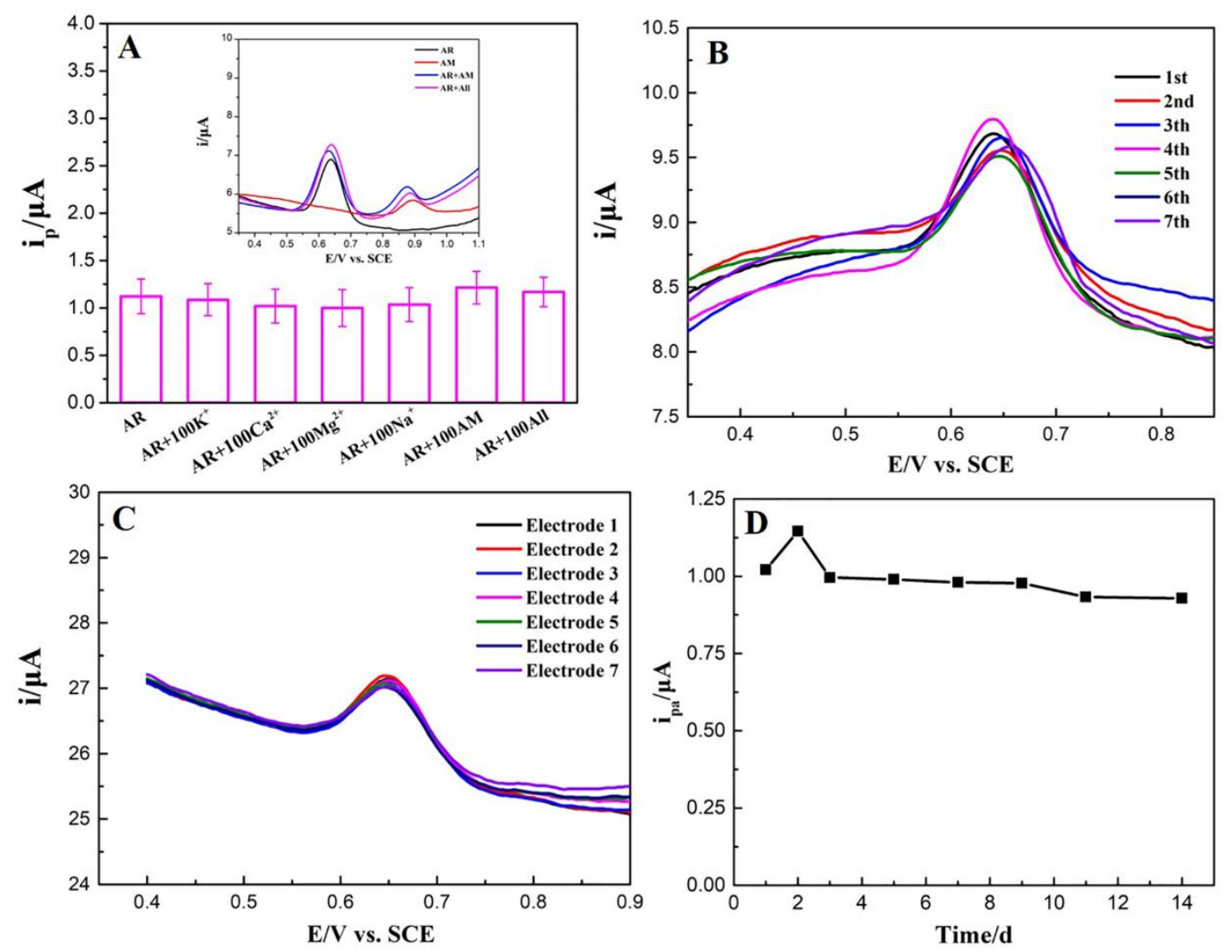

Figure 9. (A) Anodic peak current of Allura Red in the presence of 100 -fold $\mathrm{K}^{+}, \mathrm{Na}^{+}, \mathrm{Ca}^{2+}, \mathrm{Mg}^{2+}$, and amaranth; (B) Seven successive measurements of Allura Red at the same $\mathrm{TiO}_{2} / \mathrm{ErGO} / \mathrm{GCE}$; (C) Anodic peak currents of Allura Red recorded at seven $\mathrm{TiO}_{2} /$ ErGO/GCEs; (D) Anodic peak currents of Allura Red were regularly recorded during two weeks. The inset in Figure 9A is DPV of Allura Red in the existence of 100-fold amaranth and all interfering specifies. GCE: glass carbon electrodes.

\subsection{Standard Curves, Detection Range, and Detection Limit}

DPV curves of different concentrations of Allura Red are plotted in Figure 10A. Clearly, the response anodic peak currents of Allura Red increase with their concentrations. At a low concentration domain (0.3-5 $\mu \mathrm{M})$, the anodic peak currents of Allura Red are linearly correlated to their concentrations (Figure 10B). The corresponding linear equation can be expressed as $\mathrm{i}_{\mathrm{pa}}(\mu \mathrm{A})=0.0756 \mathrm{C}_{\mathrm{AR}}(\mu \mathrm{M})+0.0498$ $\left(\mathrm{R}^{2}=0.991\right)$. However, the anodic peak currents of Allura Red are positively proportional to the Napierian logarithm of their concentrations $\left(\ln C_{\mathrm{AR}}\right.$ ) ranging from 5 to $800 \mu \mathrm{M}$ (Figure $10 \mathrm{C}$ ). The standard deviation $(\sigma)$ for 10 parallel measurements in bank solution is 0.001276 . Therefore, the detection limit (LOD) is estimated to $0.05 \mu \mathrm{M}(\mathrm{LOD}=3 \sigma / \mathrm{s})$. The analytical performances including detection range and detection limit are almost comparable to previous reported modified electrodes (Table 1). In addition, $\mathrm{TiO}_{2} /$ ErGO nanohybrids possess the characteristics of low cost, available raw materials, and easy preparation, which is very advantageous for commercial applications. 

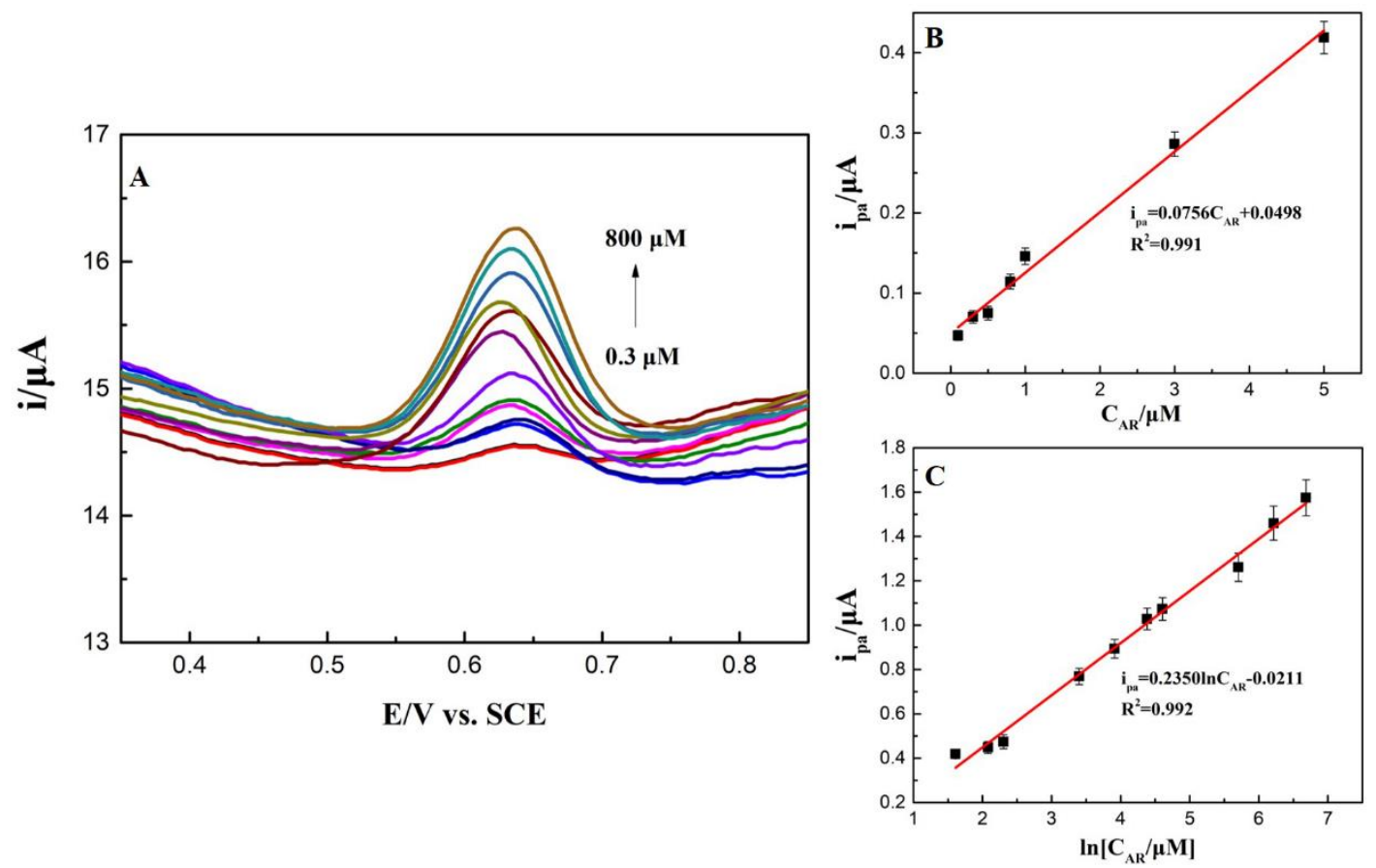

Figure 10. (A) DPV curves of Allura Red with various concentrations; (B) Linear plot of anodic peak currents of Allura Red versus their concentrations ranging from 0.3 to $5.0 \mu \mathrm{M}$; (C) Linear plot of anodic peak currents of Allura Red versus Napierian logarithm of their concentrations varying from 5.0 to $800 \mu \mathrm{M}$.

Table 1. Comparison of electroanalytical methods for the determination of Allura Red. LOD: detection limit.

\begin{tabular}{cccccc}
\hline Methods & Electrodes & Peak Potential $(\mathrm{V})$ & $\begin{array}{c}\text { Detection } \\
\text { Range }(\mu \mathrm{g} / \mathrm{L})\end{array}$ & LOD $(\mu \mathrm{g} / \mathrm{L})$ & Ref \\
\hline DPV & MWCNT/GCE & 0.68 & $50-600$ & 24.8 & {$[29]$} \\
SWV & $\mathrm{CoO}_{\mathbf{x}} / \mathrm{CPE}$ & -0.25 & $49.6-496$ & 24.8 & {$[31]$} \\
$\mathrm{DPV}$ & $\mathrm{MWCNT/GCE}$ & 0.72 & $496-4468$ & 7.0 & {$[28]$} \\
SWV & IL-EGPE & 0.72 & $500-5000$ & 0.89 & {$[30]$} \\
DPV & SbF/SPCE & -0.68 & $500-2500$ & 149 & {$[27]$} \\
SWV & $\mathrm{CoC/CPE}$ & 0.85 & $59.6-1489$ & 39.7 & {$[32]$} \\
SWV & GCE with CPB & 0.91 & $29.8-5709$ & 14.9 & {$[57]$} \\
SWV & PAMI/GCE & -0.18 & $4964-148,920$ & 695 & {$[24]$} \\
DPV & $\mathrm{TiO}_{2} / \mathrm{ErGO} / \mathrm{GCE}$ & 0.62 & $149-2482 ;$ & 24.8 & This work \\
\hline
\end{tabular}

\subsection{Determination of Allura Red in Actual Samples}

In order to verify the workability, the level of Allura Red in milk drink samples was detected by our proposed $\mathrm{TiO}_{2} / \mathrm{ErGO} / \mathrm{GCE}$ using DPV. Liziyuan drinking was diluted to 100 -fold with $0.1 \mathrm{M}$ PBS solution $(\mathrm{pH}=7.0)$. The determination results are summarized in Table 2. The concentration of Allura Red in the Liziyuan milk drink sample is $14.28 \mu \mathrm{M}(7088 \mu \mathrm{g} / \mathrm{L})$. Obviously, the level of Allura Red in soft drink is far lower than the maximum permitted dosage $(0.1 \mathrm{~g} / \mathrm{kg})$ specified in GB 2760-2014. To further verify the accuracy and precision of the proposed $\mathrm{TiO}_{2} / \mathrm{ErGO} / \mathrm{GCE}$, a series of known concentration solutions of Allura Red were spiked to the milk drink samples. The RSD is lower than $5.0 \%$ and recoveries range from $98.42 \%$ to $106.0 \%$, confirming the feasibility for the Allura Red determination in real samples. In short, the proposed $\mathrm{TiO}_{2} / \mathrm{ErGO} / \mathrm{GCE}$ shows tremendous application prospects on the determination of Allura Red in real samples such as beverages and food. 
Table 2. Determination results of Allura Red in milk drinking samples. RSD: relative standard deviation.

\begin{tabular}{ccccccc}
\hline Samples & Detected $(\boldsymbol{\mu M})$ & RSD $(\%)$ & Added $(\boldsymbol{\mu M})$ & Found $(\boldsymbol{\mu M})$ & RSD $(\%)$ & Recovery $(\%)$ \\
\hline \multirow{2}{*}{ Milk } & 14.28 & 4.26 & 1 & 15.34 & 2.81 & 106.0 \\
drinking & 14.28 & 4.26 & 10 & 24.69 & 0.85 & 104.1 \\
& 14.28 & 4.26 & 100 & 112.7 & 4.86 & 98.42 \\
\hline
\end{tabular}

Based on the detected values, it is easy to estimate the amount of Liziyuan milk drink that an individual must drink to reach Allura Red's ADI. For instance, if an individual weighs $60 \mathrm{~kg}$, the amount of Liziyuan milk drink that must consume is $59 \mathrm{~L}$ per day. This means that the volume required to reach the ADI value is so large that the potential side effects on consumers health are negligible, even if it is consumed daily.

\section{Conclusions}

In this paper, a novel electrochemical sensor based on $\mathrm{TiO}_{2} / \mathrm{ErGO}$ nanocomposites were developed for the sensitive detection of Allura Red. $\mathrm{TiO}_{2} / \mathrm{ErGO}$ nanocomposites were synthesized by the hydrolysis of titanium sulfate in graphene oxide suspension and in situ electrochemical reduction. The electrochemical characterization of the proposed sensor was performed by cyclic voltammetry and electrochemical impedance spectroscopy with $\left[\mathrm{Fe}(\mathrm{CN})_{6}\right]^{3-/ 4-}$ as the redox pair. $\mathrm{TiO}_{2} / \mathrm{ErGO}$ nanohybrids showed the largest electroactive surface area and lowest charge transferred resistance $\left(\mathrm{R}_{\mathrm{ct}}\right)$. As a result, $\mathrm{TiO}_{2} / \mathrm{ErGO} / \mathrm{GCE}$ showed remarkable electrocatalytic activity toward Allura Red, which was mainly due to the synergistic effect between $\mathrm{TiO}_{2} \mathrm{NPs}$ and ErGO nanosheets. The anodic peak currents of Allura Red were linearly correlated with their concentrations in the range of 0.3 to $5.0 \mu \mathrm{M}$. However, the linear relationship was changed to a semi-logarithmic relationship at a higher concentration region $(5.0-800 \mu \mathrm{M})$. The detection limit (LOD) was estimated to $0.05 \mu \mathrm{M}$ at SNR $=3$. Finally, the Allura Red in soft milk drink was detected by the proposed $\mathrm{TiO}_{2} / \mathrm{ErGO} / \mathrm{GCE}$ with satisfactory recovery. Featured with the fascinating merits including high sensitivity as well as good anti-jamming performance, repeatability, reproducibility, and stability, the proposed $\mathrm{TiO}_{2} / \mathrm{ErGO} / \mathrm{GCE}$ nanocomposites have become an attractive candidate for the detection of food colorants.

Author Contributions: G.L. and D.C. conceived and designed the experiments; J.W., Y.X., and J.L. performed the experiments; G.L., H.J., and Q.H. analyzed the data; G.L., Q.H., and D.C. contributed reagents/materials/analysis tools; J.W. and G.L. wrote the original draft; G.L. revised the manuscript. All authors have read and agree to the published version of the manuscript.

Funding: This work was financially supported by the Key Project of Department of Education of Guangdong Province (2016GCZX008), Project of Foshan Engineering Research Centre (20172010018), Key Disciplines' Construction Opening Fund of Foshan University (CGS06021), National Natural Science Foundation of China (No. 61703152), Natural Science Foundation of Hunan Province (No. 2019JJ50127, 2018JJ3134), Scientific Research Foundation of Hunan Provincial Education Department (18A273, 18C0522) and Undergraduates' Innovation Experiment Program of Hunan Province (No. 2018649).

Conflicts of Interest: The authors declare no conflict of interest.

\section{References}

1. Tanaka, T. Reproductive and neurobehavioural toxicity study of Ponceau $4 \mathrm{R}$ administered to mice in the diet. Food Chem. Toxicol. 2006, 44, 1651-1658. [CrossRef] [PubMed]

2. Dinç, E.; Baydan, E.; Kanbur, M.; Onur, F. Spectrophotometric multicomponent determination of sunset yellow, tartrazine and allura red in soft drink powder by double divisor-ratio spectra derivative, inverse least-squares and principal component regression methods. Talanta 2002, 58, 579-594. [CrossRef]

3. EFSA Panel on Dietetic Products (NDA). Scientific Opinion on the appropriateness of the food azo-colours Tartrazine (E 102), Sunset Yellow FCF (E 110), Carmoisine (E 122), Amaranth (E 123), Ponceau 4R (E 124), Allura Red AC (E 129), Brilliant Black BN (E 151), Brown FK (E 154), Brown HT (E 155) and Litholrubine BK (E 180) for inclusion in the list of food ingredients set up in Annex IIIa of Directive 2000/13/EC. Efsa J. 2010, 8,1778 . 
4. Yu, L.; Shi, M.; Yue, X.; Qu, L. Detection of allura red based on the composite of poly (diallyldimethylammonium chloride) functionalized graphene and nickel nanoparticles modified electrode. Sens. Actuators B 2016, 225, 398-404. [CrossRef]

5. Dixit, S.; Khanna, S.K.; Das, M. All India survey for analyses of colors in sweets and savories: Exposure risk in Indian population. J. Food Sci. 2013, 78, T642-T647. [CrossRef]

6. Soylak, M.; Unsal, Y.E.; Tuzen, M. Spectrophotometric determination of trace levels of allura red in water samples after separation and preconcentration. Food Chem. Toxicol. 2011, 49, 1183-1187. [CrossRef]

7. Minioti, K.S.; Sakellariou, C.F.; Thomaidis, N.S. Determination of 13 synthetic food colorants in water-soluble foods by reversed-phase high-performance liquid chromatography coupled with diode-array detector. Anal. Chim. Acta 2007, 583, 103-110. [CrossRef]

8. Li, X.Q.; Zhang, Q.H.; Ma, K.; Li, H.M.; Guo, Z. Identification and determination of 34 water-soluble synthetic dyes in foodstuff by high performance liquid chromatography-diode array detection-ion trap time-of-flight tandem mass spectrometry. Food Chem. 2015, 182, 316-326. [CrossRef]

9. Yoshioka, N.; Ichihashi, K.J.T. Determination of 40 synthetic food colors in drinks and candies by high-performance liquid chromatography using a short column with photodiode array detection. Talanta 2008, 74, 1408-1413. [CrossRef]

10. El-Shahawi, M.S.; Hamza, A.; Al-Sibaai, A.A.; Bashammakh, A.S.; Al-Saidi, H.M. A new method for analysis of sunset yellow in food samples based on cloud point extraction prior to spectrophotometric determination. J. Ind. Eng. Chem. 2013, 19, 529-535. [CrossRef]

11. Pourreza, N.; Rastegarzadeh, S.; Larki, A. Determination of Allura red in food samples after cloud point extraction using mixed micelles. Food Chem. 2011, 126, 1465-1469. [CrossRef]

12. Huang, H.-Y.; Shih, Y.-C.; Chen, Y.-C. Determining eight colorants in milk beverages by capillary electrophoresis. J. Chromatogr. 2002, 959, 317-325. [CrossRef]

13. Huang, H.-Y.; Chiu, C.-W.; Sue, S.-L.; Cheng, C.-F. Analysis of food colorants by capillary electrophoresis with large-volume sample stacking. J. Chromatogr. 2003, 995, 29-36. [CrossRef]

14. Wu, Y.; Deng, P.; Tian, Y.; Magesa, F.; Liu, J.; Li, G.; He, Q. Construction of effective electrochemical sensor for the determination of quinoline yellow based on different morphologies of manganese dioxide functionalized graphene. J. Food Compos. 2019, 84, 103280. [CrossRef]

15. Li, G.; Zhong, P.; Ye, Y.; Wan, X.; Cai, Z.; Yang, S.; Xia, Y.; Li, Q.; Liu, J.; He, Q. A Highly Sensitive and Stable Dopamine Sensor Using Shuttle-Like $\alpha-\mathrm{Fe}_{2} \mathrm{O}_{3}$ Nanoparticles/Electro-Reduced Graphene Oxide Composites. J. Electrochem. Soc. 2019, 166, B1552-B1561. [CrossRef]

16. Li, G.; Xia, Y.; Tian, Y.; Wu, Y.; Liu, J.; He, Q.; Chen, D. Recent Developments on Graphene-Based Electrochemical Sensors toward Nitrite. J. Electrochem. Soc. 2019, 166, B881-B895. [CrossRef]

17. He, Q.; Liu, J.; Xia, Y.; Tuo, D.; Deng, P.; Tian, Y.; Wu, Y.; Li, G.; Chen, D. Rapid and Sensitive Voltammetric Detection of Rhodamine B in Chili-Containing Foodstuffs Using $\mathrm{MnO}_{2}$ Nanorods/Electro-Reduced Graphene Oxide Composite. J. Electrochem. Soc. 2019, 166, B805-B813. [CrossRef]

18. He, Q.; Liu, J.; Liu, X.; Li, G.; Deng, P.; Liang, J. Manganese dioxide nanorods/electrochemically reduced graphene oxide nanocomposites modified electrodes for cost-effective and ultrasensitive detection of Amaranth. Colloids Surf. B 2018, 172, 565-572. [CrossRef]

19. Qian, Y.; Wang, C.; Gao, F. Ultrasensitive electrochemical detection of DNA based on Zn2+ assistant DNA recycling followed with hybridization chain reaction dual amplification. Biosens. Bioelectron. 2015, 63, 425-431. [CrossRef]

20. Qian, Y.; Tang, D.; Du, L.; Zhang, Y.; Zhang, L.; Gao, F. A novel signal-on electrochemical DNA sensor based on target catalyzed hairpin assembly strategy. Biosens. Bioelectron. 2015, 64, 177-181. [CrossRef]

21. Qian, Y.; Gao, F.; Du, L.; Zhang, Y.; Tang, D.; Yang, D. A novel label-free and enzyme-free electrochemical aptasensor based on DNA in situ metallization. Biosens. Bioelectron. 2015, 74, 483-490. [CrossRef] [PubMed]

22. López-de-Alba, P.L.; López-Martínez, L.; De-León-Rodríguez, L.M. Simultaneous determination of synthetic dyes tartrazine, allura red and sunset yellow by differential pulse polarography and partial least squares. A multivariate calibration method. Electroanalysis 2002, 14, 197-205. [CrossRef]

23. Chanlon, S.; Joly-Pottuz, L.; Chatelut, M.; Vittori, O.; Cretier, J. Determination of Carmoisine, Allura red and Ponceau $4 \mathrm{R}$ in sweets and soft drinks by Differential Pulse Polarography. J. Food Compos. Anal. 2005, 18, 503-515. [CrossRef] 
24. Silva, M.L.S.; Garcia, M.B.Q.; Lima, J.L.F.C.; Barrado, E. Voltammetric determination of food colorants using a polyallylamine modified tubular electrode in a multicommutated flow system. Talanta 2007, 72, 282-288. [CrossRef]

25. Xie, X.Y.; Luo, H.Q.; Li, N.B. Determination of azo compounds by differential pulse voltammetry at a bismuth/poly (p-aminobenzene sulfonic acid) film electrode and application for detection in food stuffs. J. Electroanal. Chem. 2010, 639, 175-180. [CrossRef]

26. Claux, B.; Vittori, O. Bismuth film electrode as an alternative for mercury electrodes: Determination of azo dyes and application for detection in food stuffs. Electroanalysis 2007, 19, 2243-2246. [CrossRef]

27. Rodríguez, J.A.; Juárez, M.G.; Galán-Vidal, C.; Miranda, J.; Barrado, E. Determination of allura red and tartrazine in food samples by sequential injection analysis combined with voltammetric detection at antimony film electrode. Electroanalysis 2015, 27, 2329-2334. [CrossRef]

28. Sierra-Rosales, P.; Toledo-Neira, C.; Ortúzar-Salazar, P.; Squella, J.A. MWCNT-modified Electrode for Voltammetric Determination of Allura Red and Brilliant Blue FCF in Isotonic Sport Drinks. Electroanalysis 2019, 31, 883-890. [CrossRef]

29. Zhang, Y.; Zhang, X.; Lu, X.; Yang, J.; Wu, K. Multi-wall carbon nanotube film-based electrochemical sensor for rapid detection of Ponceau $4 \mathrm{R}$ and Allura Red. Food Chem. 2010, 122, 909-913. [CrossRef]

30. Zhang, J.; Zhang, S.; Wang, X.; Wang, W.; Chen, Z. Simultaneous determination of Ponceau-4R and Allura Red in soft drinks based on the ionic liquid modified expanded graphite paste electrode. Int. J. Environ. Anal. Chem. 2015, 95, 581-591. [CrossRef]

31. Penagos-Llanos, J.; García-Beltrán, O.; Calderón, J.A.; Nagles, E.; Hurtado, J. Carbon Paste Composite with $\mathrm{Co}_{3} \mathrm{O}_{4}$ as a New Electrochemical Sensor for the Detection of Allura Red by Reduction. Electroanalysis 2019, 31, 695-703. [CrossRef]

32. Penagos-Llanos, J.; García-Beltrán, O.; Calderón, J.A.; Hurtado-Murillo, J.J.; Nagles, E.; Hurtado, J.J. Simultaneous determination of tartrazine, sunset yellow and allura red in foods using a new cobalt-decorated carbon paste electrode. J. Electroanal. Chem. 2019, 852, 113517. [CrossRef]

33. Zhou, W.-Y.; Liu, J.-Y.; Song, J.-Y.; Li, J.-J.; Liu, J.-H.; Huang, X.-J. Surface-electronic-state-modulated, single-crystalline (001) $\mathrm{TiO}_{2}$ nanosheets for sensitive electrochemical sensing of heavy-metal ions. Anal. Chem. 2017, 89, 3386-3394. [CrossRef] [PubMed]

34. Shehata, M.; Azab, S.; Fekry, A.; Ameer, M.J.B. Bioelectronics. Nano- $\mathrm{TiO}_{2}$ modified carbon paste sensor for electrochemical nicotine detection using anionic surfactant. Biosens. Bioelectron. 2016, 79, 589-592. [CrossRef] [PubMed]

35. Bao, S.J.; Li, C.M.; Zang, J.F.; Cui, X.Q.; Qiao, Y.; Guo, J. New nanostructured $\mathrm{TiO}_{2}$ for direct electrochemistry and glucose sensor applications. Adv. Funct. Mater. 2008, 18, 591-599. [CrossRef]

36. Fan, Y.; Huang, K.-J.; Niu, D.-J.; Yang, C.-P.; Jing, Q.-S. $\mathrm{TiO}_{2}$-graphene nanocomposite for electrochemical sensing of adenine and guanine. Electrochim. Acta 2011, 56, 4685-4690. [CrossRef]

37. Benvenuto, P.; Kafi, A.; Chen, A. High performance glucose biosensor based on the immobilization of glucose oxidase onto modified titania nanotube arrays. J. Electroanal. Chem. 2009, 627, 76-81. [CrossRef]

38. Tong, H.; Zhao, L.; Li, D.; Zhang, X. N, Fe and $\mathrm{WO}_{3}$ modified $\mathrm{TiO}_{2}$ for degradation of formaldehyde. J. Alloy Compd. 2011, 509, 6408-6413. [CrossRef]

39. Zhou, Y.; Huang, Y.; Li, D.; He, W. Three-dimensional sea-urchin-like hierarchical $\mathrm{TiO}_{2}$ microspheres synthesized by a one-pot hydrothermal method and their enhanced photocatalytic activity. Mater. Res. Bull. 2013, 48, 2420-2425. [CrossRef]

40. Li, C.; Zhang, S.; Zhou, Y.; Li, J. A situ hydrothermal synthesis of a two-dimensional $\mathrm{MoS}_{2} / \mathrm{TiO}_{2}$ heterostructure composite with exposed (001) facets and its visible-light photocatalytic activity. J. Mater. Sci. Mater. Electron. 2017, 28, 9003-9010. [CrossRef]

41. Chen, C.; Cao, S.; Long, H.; Qian, G.; Tsang, Y.; Gong, L.; Yu, W.; Xiao, Y. Highly efficient photocatalytic performance of graphene oxide/ $/ \mathrm{TiO}_{2}-\mathrm{Bi}_{2} \mathrm{O}_{3}$ hybrid coating for organic dyes and NO gas. J. Mater. Sci. Mater. Electron. 2015, 26, 3385-3391. [CrossRef]

42. Dang, M.; Zhou, Y.; Li, H.; Lv, C. Preparation and photocatalytic activity of $\mathrm{N}$-doped $\mathrm{TiO}_{2}$ nanotube array films. J. Mater. Sci. Mater. Electron. 2012, 23, 320-324. [CrossRef]

43. Daniel, D.; Gutz, I.G.R. Microfluidic cell with a $\mathrm{TiO}_{2}$-modified gold electrode irradiated by an UV-LED for in situ photocatalytic decomposition of organic matter and its potentiality for voltammetric analysis of metal ions. Electrochem. Commun. 2007, 9, 522-528. [CrossRef] 
44. Wan, X.; Yang, S.; Cai, Z.; He, Q.; Ye, Y.; Xia, Y.; Li, G.; Liu, J. Facile Synthesis of $\mathrm{MnO}_{2}$ Nanoflowers/N-Doped Reduced Graphene Oxide Composite and Its Application for Simultaneous Determination of Dopamine and Uric Acid. Nanomaterials 2019, 9, 847. [CrossRef] [PubMed]

45. Cai, Z.; Ye, Y.; Wan, X.; Liu, J.; Yang, S.; Xia, Y.; Li, G.; He, Q. Morphology-Dependent Electrochemical Sensing Properties of Iron Oxide-Graphene Oxide Nanohybrids for Dopamine and Uric Acid. Nanomaterials 2019, 9, 835. [CrossRef]

46. He, Q.; Liu, J.; Liu, X.; Li, G.; Chen, D.; Deng, P.; Liang, J. A promising sensing platform toward dopamine using $\mathrm{MnO}_{2}$ nanowires/electro-reduced graphene oxide composites. Electrochim. Acta 2019, 296, 683-692. [CrossRef]

47. He, Q.; Wu, Y.; Tian, Y.; Li, G.; Liu, J.; Deng, P.; Chen, D. Facile electrochemical sensor for nanomolar rutin detection based on magnetite nanoparticles and reduced graphene oxide decorated electrode. Nanomaterials 2019, 9, 115. [CrossRef]

48. Li, Q.; Xia, Y.; Wan, X.; Yang, S.; Cai, Z.; Ye, Y.; Li, G. Morphology-dependent $\mathrm{MnO}_{2} /$ nitrogen-doped graphene nanocomposites for simultaneous detection of trace dopamine and uric acid. Mater. Sci. Eng. C 2020, 109, 110615. [CrossRef]

49. Kamat, P.V. Graphene-based nanoarchitectures. Anchoring semiconductor and metal nanoparticles on a two-dimensional carbon support. J. Phys. Chem. Lett. 2009, 1, 520-527. [CrossRef]

50. Jang, H.D.; Kim, S.K.; Chang, H.; Roh, K.-M.; Choi, J.-W.; Huang, J. A glucose biosensor based on $\mathrm{TiO}_{2}$-graphene composite. Biosens. Bioelectron. 2012, 38, 184-188. [CrossRef]

51. Fan, Y.; Lu, H.-T.; Liu, J.-H.; Yang, C.-P.; Jing, Q.-S.; Zhang, Y.-X.; Yang, X.-K.; Huang, K.-J. Hydrothermal preparation and electrochemical sensing properties of $\mathrm{TiO}_{2}$-graphene nanocomposite. Colloids Surf. B 2011, 83, 78-82. [CrossRef] [PubMed]

52. Fan, Y.; Liu, J.-H.; Lu, H.-T.; Zhang, Q. Electrochemical behavior and voltammetric determination of paracetamol on Nafion/ $/ \mathrm{TiO}_{2}$-graphene modified glassy carbon electrode. Colloids Surf. B 2011, 85, 289-292. [CrossRef] [PubMed]

53. Fan, Y.; Liu, J.-H.; Lu, H.-T.; Zhang, Q. Electrochemistry and voltammetric determination of L-tryptophan and L-tyrosine using a glassy carbon electrode modified with a Nafion/TiO 2 -graphene composite film. Microchim. Acta 2011, 173, 241-247. [CrossRef]

54. Alamdari, S.; Ghamsari, M.S.; Afarideh, H.; Mohammadi, A.; Geranmayeh, S.; Tafreshi, M.J.; Ehsani, M.H. Preparation and characterization of GO-ZnO nanocomposite for UV detection application. Opt. Mater. 2019, 92, 243-250. [CrossRef]

55. Guangli, L.; Jingtao, W.; Yonghui, X.; Yiyong, W.; Yaling, T.; Jun, L.; Dongchu, C.; Quanguo, H. Towards emerging EEG applications: A novel printable flexible $\mathrm{Ag} / \mathrm{AgCl}$ dry electrode array for robust recording EEG signals at forehead sites. J. Neural Eng. 2020. [CrossRef]

56. Li, G.; Wang, S.; Duan, Y.Y. Towards conductive-gel-free electrodes: Understanding the wet electrode, semi-dry electrode and dry electrode-skin interface impedance using electrochemical impedance spectroscopy fitting. Sens. Actuators B 2018, 277, 250-260. [CrossRef]

57. Nagles, E.; Garcia-Beltran, O. Determination of Allura Red in the Presence of Cetylpyridinium Bromide by Square-wave Adsorptive Stripping Voltammetry on a Glassy Carbon Electrode. Anal. Sci. 2018, 34, 1171-1175. [CrossRef]

58. Laviron, E. General expression of the linear potential sweep voltammogram in the case of diffusionless electrochemical systems. J. Electroanal. Chem. 1979, 101, 19-28. [CrossRef]

59. Laviron, E. Adsorption, autoinhibition and autocatalysis in polarography and in linear potential sweep voltammetry. J. Electroanal. Chem. Interfacial Electrochem. 1974, 52, 355-393. [CrossRef]

(C) 2020 by the authors. Licensee MDPI, Basel, Switzerland. This article is an open access article distributed under the terms and conditions of the Creative Commons Attribution (CC BY) license (http://creativecommons.org/licenses/by/4.0/). 